7. Reprod. Fert. (1970) 21, 171-175

\title{
DISSOCIATION OF UTEROTROPHIC ACTION FROM IMPLANTATION-INDUCING ACTIVITY IN TWO NON-STEROIDAL OESTROGENS (COUMESTROL AND GENISTEIN)
}

\author{
E. PEREL AND H. R. LINDNER
}

Department of Biodynamics, Weizmann Institute of Science, Rehovot, Israel

(Received 19th Fune 1969)

\begin{abstract}
Summary. The phyto-oestrogens coumestrol (7,12-dihydroxycoumestan) and genistein (5,7,4'-trihydroxyisoflavone) induced uterine growth in ovariectomized rats, but failed to induce ovum implantation in mated ovariectomized, gestagen-maintained rats and in intact lactating rats when given at dose levels effective in uterine weight assays. Oestradiol$17 \beta$, under similar conditions, induced ovum implantation even at dose levels below those required for a uterine weight response. Diethylstilboestrol and large doses of oestradiol- $17 \alpha$ (5 to $10 \mu \mathrm{g}$ ) were effective in both assays. It is suggested that different uterine receptors may be involved in mediating the uterine-growth-promoting and implantationinducing actions of oestrogen.
\end{abstract}

The phyto-oestrogens coumestrol (7,12-dihydroxycoumestan) and genistein $\left(5,7,4^{\prime}\right.$-trihydroxyisoflavone) are able to mimic some of the actions of steroidal oestrogens, e.g. to stimulate uterine growth in ovariectomized mice (Bickoff, Booth, Lyman, Livingston, Thompson \& DeEds, 1957; Wong \& Flux, 1962) and sheep (Braden, Hart \& Lamberton, 1967; Lindner, 1967; Shutt, Braden \& Lindner, 1969). Another characteristic action of steroidal oestrogens is their ability to induce implantation of the dormant blastocyst in the ovariectomized, progesterone-maintained rat (Krehbiel, 1941; Canivenc \& Laffargue, 1956; Shelesnyak, 1959; Mayer \& Meunier, 1959; Psychoyos, 1961; Nutting \& Meyer, 1963). We wished to examine whether the latter response could also be elicited, or modified, by non-steroidal oestrogens.

Three-month-old Wistar-derived rats (with a body weight of $207 \mathrm{~g} \pm 1 \cdot 5 \mathrm{~S}$.E.) were fed unrestricted Purina Laboratory Chow (Ralston Purina Co., St. Louis) and maintained under 14-hr daylight cycles. For uterine weight assays, rats were ovariectomized 14 days before use. In the 6 -hr test, a single subcutaneous (s.c.) injection of coumestrol or genistein dissolved in $0.1 \mathrm{ml}$ dimethylsulphoxide (DMSO) was given, and a total of sixty-two to seventy-six animals was used for each substance in a five-point assay (Text-fig. 1, a and b). The increase in the weight of the uterus $6 \mathrm{hr}$ after injection was expressed as a percentage of the uterine weight in vehicle-injected controls. In the $3 \frac{1}{2}$-day test, half the daily 

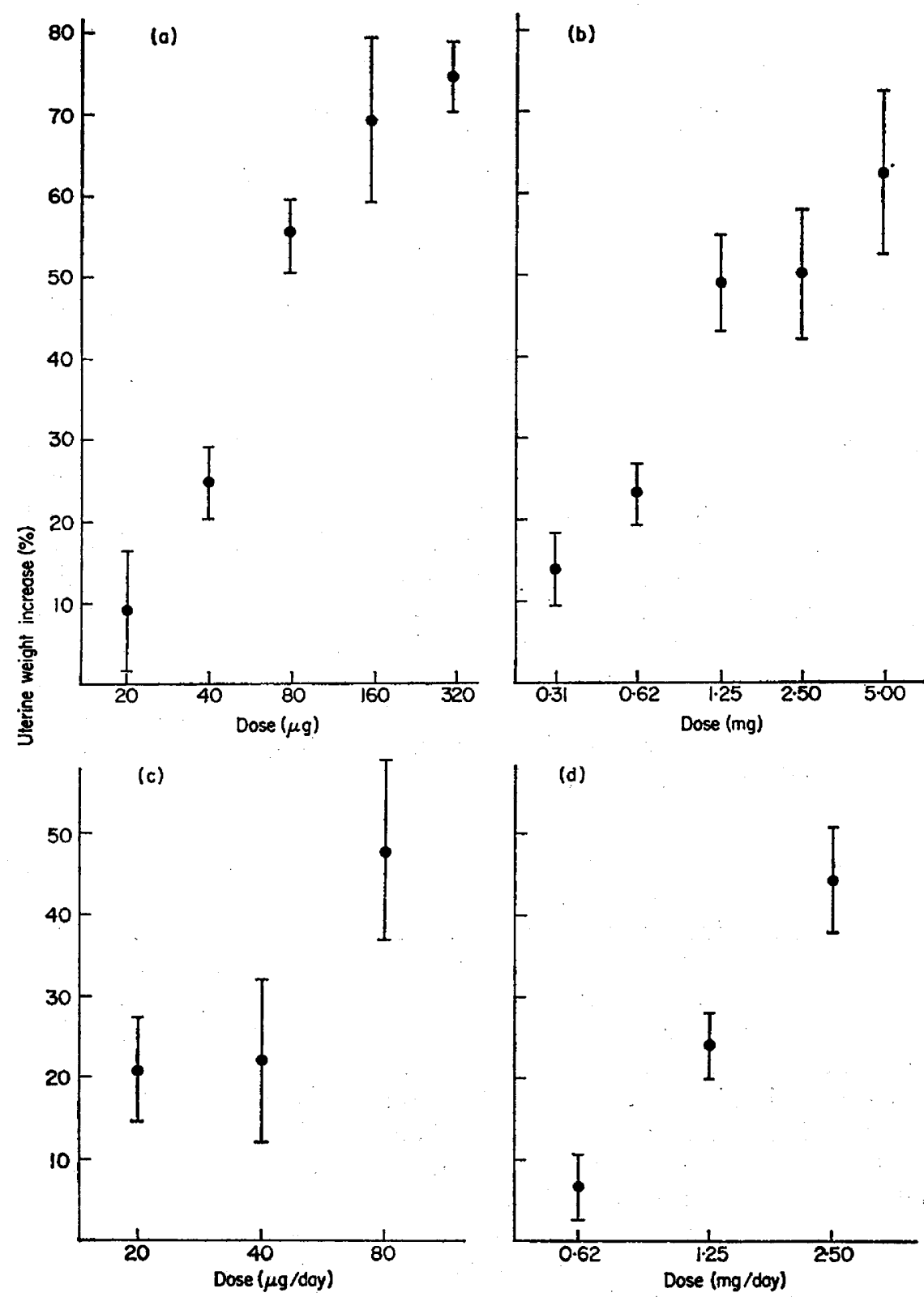

Text-pio. 1. Effect of subcutaneous injection of phyto-oestrogens on uterine weight in mature, ovariectomized rats. Response, expressed as percentage increase over mean weight of uterus in vehicle-injected controls, is shown as a function of log-dose. (a) and (b), 6-hr test; (c) and (d), 3t-day test; (a) and (c), coumestrol; (b) and (d), genistein. 
dose of coumestrol or genistein in $0.1 \mathrm{ml} \mathrm{DMSO}$, or $0.1 \mathrm{ml}$ of the vehicle, was injected s.c. on the morning and afternoon of Days 1 to 3 and on the morning of Day 4, using from thirty to thirty-six animals for each substance in a threepoint assay (Text-fig. 1, c and d). The rats were killed on the afternoon of the 4th day and the uteri were dissected out and weighed.

To test for implantation-inducing or -inhibiting action, mated rats were given $4 \mathrm{mg}$ progesterone in arachis oil intramuscularly (i.m.) at 15.00 hours on the

TABLE 1

EFFECT OF VARIOUS OESTROGENS ON OVUM IMPLANTATION IN OVARIECTOMIZED, PROGESTAGEN-TREATED RATS

\begin{tabular}{|c|c|c|c|c|}
\hline Compound & $\begin{array}{c}\text { Dose* } \\
(\mu g)\end{array}$ & $\begin{array}{l}\text { Rats with } \\
\text { implants }\end{array}$ & $\begin{array}{c}\text { Implants| } \\
\text { pregnant rat }\end{array}$ & $\begin{array}{c}\text { Free ova recovered/ } \\
\text { non-pregnant rat }\end{array}$ \\
\hline Vehicle only & - & $0 / 11$ & 0 & $4 \cdot 9$ \\
\hline Oestradiol-17 $\beta$ & $\begin{array}{c}0.06 \\
0.08 \text { to } 0.16\end{array}$ & $\begin{array}{r}8 / 12 \\
34 / 37\end{array}$ & $\begin{array}{l}7 \\
5 \cdot 1\end{array}$ & $\begin{array}{l}0 \\
0\end{array}$ \\
\hline Oestradiol-17 $1 \alpha$ & $\begin{array}{l}2 \cdot 5 \\
5 \text { to } 10\end{array}$ & $\begin{array}{c}1 / 7 \\
25 / 27\end{array}$ & $\begin{array}{l}2 \\
5 \cdot 5\end{array}$ & $\begin{array}{l}3 \cdot 7 \\
0\end{array}$ \\
\hline Diethylstilboestrol & 1 & $8 / 10$ & $7 \cdot 7$ & 1 \\
\hline Coumestrol & 20 to 480 & $2 / 92$ & $4 \cdot 2$ & $3 \cdot 3$ \\
\hline $\begin{array}{l}\text { Oestradiol-17 } \beta \\
\text { plus } \\
\text { Coumestrol }\end{array}$ & $\begin{array}{l}0.08 \\
160 \dagger\end{array}$ & $36 / 39$ & $6 \cdot 6$ & 0 \\
\hline Genistein & 312 to 3750 & $5 / 101$ & $8 \cdot 6$ & $4 \cdot 3$ \\
\hline $\begin{array}{l}\text { Oestradiol-17 } \beta \\
\text { plus } \\
\text { Genistein }\end{array}$ & $\begin{array}{l}0 \cdot 10 \\
1250 \dagger\end{array}$ & $41 / 41$ & $6 \cdot 1$ & $\mathbf{0}$ \\
\hline
\end{tabular}

* In $0.1 \mathrm{ml}$ dimethylsulphoxide or arachis oil by single injection s.c. or i.m. or in three divided doses at 3-hr intervals. Results of treatment groups that did not differ significantly were combined.

$\dagger$ Given at the same time as oestradiol, or preceding it by $1 \frac{1}{2}, 3$ or $24 \mathrm{hr}$.

3rd day post coitum (p.c.), and were ovariectomized at 08.00 to 09.00 hours on Day 4 p.c. An aqueous suspension of medroxyprogesterone acetate (DepoProvera, Upjohn Co.; $15 \mathrm{mg}$ in $0.3 \mathrm{ml}$ ) was injected s.c. at 15.00 hours on Day 9 p.c. The test substance was injected on Day 10 p.c., as indicated in Table 1 . In general, the animals were killed on Day 15 p.c. and the uteri examined for implantation sites. If none was found, the uteri were flushed with $0.25 \mathrm{ml}$ saline and the flushings searched for free ova under a dissecting microscope. In some experiments, however, Provera injection was repeated on Day 14 p.c. and the animals were killed and examined on Day 20 p.c. to check whether implantation had occurred at a still later stage due to delayed absorption from the injection site of the sparingly soluble phyto-oestrogens. In a further group of experiments, intact rats were mated at the post partum oestrus and litter size adjusted to eleven young each, the number found sufficient to cause a delay in implantation in more than $90 \%$ of the animals (gestation $=28$ days \pm 0.47 S.E.). The test substance was injected on Day 4 p.c. and the date of delivery noted. 
Both coumestrol and genistein caused an increase in the weight of the uterus of ovariectomized rats (Text-fig. 1). In the 6-hr assay (Text-fig. 1, a and b), which probably reflects mainly water imbibition (Astwood, 1938), $40 \mu \mathrm{g}$ coumestrol or $0.62 \mathrm{mg}$ genistein gave significant responses; $80 \mu \mathrm{g}$ coumestrol, $1.25 \mathrm{mg}$ genistein or $0.5 \mu \mathrm{g}$ oestradiol- $17 \beta$ caused a $50 \%$ increase, approximately, in uterine weight. In the $3 \frac{1}{2}$-day assay (Text-fig. 1 , c and d), 40 to $80 \mu$ g coumestrol or $1.25 \mathrm{mg}$ genistein were required for a significant uterine growth response. Only the higher coumestrol dose $(80 \mu \mathrm{g})$, and none of the genistein dose levels used, brought about vaginal cornification.

A single injection of $0.06 \mu \mathrm{g}$ oestradiol-17 $\beta$ induced ovum implantation in $67 \%$ of the mated, ovariectomized, gestagen-treated rats; 0.08 to $0.16 \mu \mathrm{g}$ of oestradiol-17 $\beta$ was effective in 91 to $100 \%$ of animals (Table 1; cf. Psychoyos, 1965). These amounts of oestradiol are just below the minimal dose level that gave a detectable uterine weight response in mature ovariectomized rats in the two assay systems used. Oestradiol-17 $\alpha$ (5 to $10 \mu \mathrm{g}$ ) and dimethyl stilboestrol (1 $\mu \mathrm{g}$-lower doses were not tested) were also effective in inducing ovum implantation (Table 1), as well as uterine water imbibition. Both activities may represent inherent properties of oestradiol-1 $7 \alpha$. Alternatively, the presence of as little as $2 \%$ of the $17 \beta$-epimer as an impurity could have accounted for the observed effects, and the presence of such an impurity was not definitely excluded. However, two preparations derived from different sources (Organon Ltd and Mann Research Laboratories) gave similar results.

In contrast to these complete oestrogens, neither coumestrol nor genistein was able to induce ovum implantation when given at dose levels effective in uterine weight assays (Table 1): coumestrol dose levels employed ranged from $20 \mu \mathrm{g}$ by single injection given at 12.00 hours on Day 10 p.c. to $480 \mu \mathrm{g}$ in three divided doses given at $09.00,12.00$ and 15.00 hours, and those of genistein from $0.31 \mathrm{mg}$ to $3 \times 1.250 \mathrm{mg}$. Sporadic implantations observed in these rats (in seven out of 193 animals) were unrelated to dose level and are probably attributable to incomplete ovariectomies. Administration of genistein (1.25 to $2.5 \mathrm{mg}$ ) or coumestrol (160 to $480 \mu \mathrm{g}$ ) on Day 4 p.c. by single injection or in two to three divided doses was equally ineffective in advancing the time of implantation in intact lactating rats (gestation periods $=28$ days \pm 0.45 S.E. and 28 days \pm 0.60 , respectively), whereas oestradiol- $17 \beta(0.1$ to $0.2 \mu \mathrm{g}$ on Day 4 p.c.) was fully effective in inducing early implantation (gestation $=22$ days \pm 0.18 S.E.) in such animals. The administration of coumestrol $(160 \mu \mathrm{g})$ or genistein $(1.25 \mathrm{mg})$ together with an adequate dose of oestradiol-17 $\beta(0.1 \mu \mathrm{g})$, or at various time intervals ( $1 \frac{1}{2}$ to $24 \mathrm{hr}$ ) before the steroidal oestrogen (Table 1), did not impair the implantation-inducing action of oestradiol.

The $3 \frac{1}{2}$-day uterine weight response is not entirely specific for oestrogens, large doses of androgens or progestagens being known to exert a similar effect (Emmens, 1962). Like oestradiol, coumestrol diacetate and genistein stimulate the incorporation of labelled precursors into protein, lipid and RNA by the rat uterus (Noteboom \& Gorski, 1963). Furthermore, administration of coumestrol $(80 \mu \mathrm{g})$ or genistein $(0.62 \mathrm{mg})$ in DMSO was shown to enhance uterine vascular permeability within $2 \mathrm{hr}$ of injection in immature rats, as indicated by rapid uptake by the uterus of intravenously injected Evans blue (Catchpole \& 
Lindner, unpublished observations). This blueing reaction is regarded as a characteristic feature of the receptive pre-implantation uterus (Psychoyos, 1960). It was the more surprising that no dosage régime of the two phytooestrogens was found that would bring about ovum implantation in the progestagen-primed uterus. Neither did these phyto-oestrogens inhibit the implantation-inducing action of oestradiol, as might have been expected from reports that certain plant oestrogens, including genistein, are able to displace oestradiol from vaginal and uterine oestrogen receptor sites (Shutt, 1967; Terenius, 1968). The present results suggest that different cellular receptors may be involved in mediating the uterine-growth-promoting and the implantation-inducing action of oestrogen.

We are grateful to Mrs A. Tandlich and Mr S. Joseph for skilful assistance, to Dr E. M. Bickoff for a generous gift of coumestrol and to the Upjohn Company for the free supply of Depo-Provera. The work was supported by the Ford Foundation and the Population Council.

\section{REFERENCES}

Astwood, E. G. (1938) A six-hour assay for the quantitative determination of estrogen. Endocrinology, $23,25$.

Bickoff, E. M., Booth, A. N., Lyman, R. L., Livingston, A. L., Thompson, C. R. \& DeEds, F. (1957) Coumestrol, a new estrogen isolated from forage crops. Science, N.Y. 126, 969.

Braden, A. W. H., Hart, N. K. \& Lamberton, J. A. (1967) The oestrogenic activity and metabolism of certain isoflavones in sheep. Aust. 7. agric. Res. 18, 335.

Canivenc, R. \& Laffargur, M. (1956) Survie prolongée d'œufs fécondés non-implantés dans l'utérus de rattes castrées et injectées de progestérone. C.r. hebd. Séanc. Acad. Sci., Paris, 242, 2857.

Emmens, C. W. (1962) Estrogens. In: Methods in Hormone Research, p. 59. Ed. R. I. Dorfman. Academic Press, New York.

KREHBieL, R. H. (1941) The effects of theelin on delayed implantation in the pregnant lactating rat. Anat. Rec. 81, 381.

LiNDNER, H. R. (1967) Study of the fate of phyto-oestrogens in the sheep by determination of isoflavones and coumestrol in the plasma and adipose tissue. Aust. J. agric. Res. 18, 305.

Mayer, G. \& Meunier, J. M. (1959) Réserpine et progestation chez la ratte; survie des œufs en phase latente et ovoimplantations normales ou retardées, provoquées par l'oestrogène. C.r. hebd. Séanc. Acad. Sci., Paris, 248, 3355.

Noteboom, W. D. \& Gorski, J. (1963) Estrogenic effects of genistein and coumestrol diacetate. Endocrinology, 73, 736.

Nutting, E. F. \& Meyer, R. K. (1963) Implantation delay, nidation and embryonal survival in rats treated with ovarian hormones. In: Delayed Implantation, p. 233. Ed. A. C. Enders. University of Chicago Press.

Psychoyos, A. (1960) Nouvelle contribution a l'étude de la nidation de l'œuf chez la ratte. C.r. hebd. Séanc. Acad. Sci., Paris, 251, 3073.

Psychoyos, A. (1961) La nidation chez la ratte et la dose d'oestrogène nécessaire. C.r. hebd. Séanc. Acad. Sci., Paris, 253, 1616.

Psychoyos, A. (1965) Contrôle de la nidation chez les mammifères. Arch. Anat. microsc. Morph. exp. 54,85 .

Shelesnyak, M. C. (1959) Nidation of the fertilized ovum. Endeavour, 19, 81.

SHuTt, D. A. (1967) Interaction of genistein with oestradiol in the reproductive tract of the ovariectomized mouse. 7. Endocr. 37, 231.

Shutt, D. A., Braden, A. W. H. \& Lindner, H. R. (1969) Plasma coumestrol levels in sheep following administration of synthetic coumestrol or ingestion of medic hay (Medicago littoralis). Aust. $\mathcal{J}$. agric. Res. 20, 65.

Terenius, L. (1968) Structural features of oestrogen-binding by the mouse uterus: inhibition of $17 \beta$ oestradiol binding in vitro by a plant oestrogen, miroestrol. Acta pharmac. tox. $26,15$.

Wong, E. \& Flux, D. S. (1962) The oestrogenic activity of red clover isoflavones and some of their degradation products. 7 . Endocr. 24, 341 . 